\title{
TATUAGEM: CULTURA DE MASSAS E AFIRMAÇÃO SUBJETIVA INCORPORADAS
}

\section{Tattoos: Mass culture and affimation subjective emerged}

\author{
Maria Ângela Pavan ${ }^{1}$ \\ Josimey C. Silva ${ }^{2}$
}

\section{Resumo}

Como afirmar a própria subjetividade e pertenças identitárias num mundo em constante mudança pelo excesso de informação midiática e pela alternância de papéis sociais? Para jovens urbanos, o consumo cultural possibilita utilizar a imagem do próprio corpo como instância de incorporação de valores, símbolos midiáticos e expressão de subjetividade a partir de sua escolha por produtos simbólicos veiculados pela mídia da comunicação de massa e tatuados na pele. Com suporte principal em Hall, Canclíni, Morin e Le Breton, partimos do pressuposto de que não existe realidade sem representação da linguagem; assim, a opção por certos tipos de narradores midiáticos da cultura contemporânea põe em foco o simbolismo sobreposto à pele, que reproduz imagens icônicas de bandas, filmes e desenhos animados ou de quadrinhos. Essas imagens são resíduos de memórias individuais/coletivas ostentadas socialmente e que discursam sobre as relações de consumo dos sujeitos sociais e as novas sensibilidades originadas da convivência tecnologicamente midiatizada.

Palavras-chave: Cultura, consumo, corpo, comunicação, subjetividade.

\begin{abstract}
How to affirm your own subjectivity and identity belongings in a world constantly changing because of the overload of media information, and social role changing? For urban youth, cultural consumption enables the use of their body image as a forum to incorporate values, mediatic symbols, and expression of subjectivity by their choice of symbolic products conveyed by the mass media and tattooed on their skin. With major support in Hall, Canclini, Morin and Le Breton, we assume that there is no reality without the representation of

\footnotetext{
${ }^{1}$ Doutora em Multimeios plea UNICAMP; professora do Departamento de Comunicação da UFRN e membro do Grupo Pragma - Pragmática da Comunicação e Mídia: teorias, linguagens, indústrias culturais e cidadania da UFRN. Membro do Grupo de Estudos e Pesquisas sobre Linguagem e Narrativas da UNESP.

${ }^{2}$ Doutora em Ciências Sociais/Antropologia pela PUC-SP; professora do Departamento de Comunicação Social, do Programa de Pós Graduação em Estudos de Mídia e do Programa de Pós-Graduação em Ciências Sociais, todos da UFRN.
} 
language; therefore, the choice of certain types of narrators in contemporary culture media spotlights the symbolism overlaid on the skin, which reproduces iconic images of bands, movies and cartoons or comics. These images are residues of individual / collective memories sported socially and speech on consumption relations of social subjects and new sensitivities arising from the technologically mediated coexistence.

Keywords: Culture, comsumption, body, communication, subjectivity.

\section{Resumen}

¿Cómo afirmar su propia subjetividad y la identidad de pertenencia en un mundo cambiante por los medios y la sobrecarga de información por cambio de roles? Para los jóvenes urbanos, el consumo cultural permite usar la imagen de su propio cuerpo como un foro para la incorporación de valores, símbolos, medios de comunicación y expresión de la subjetividad de su elección de productos simbólicos que transmiten los medios de comunicación de masas y la piel tatuada. Con un importante apoyo en el pabellón Canclini, Morin y Breton Le, suponemos que no hay una realidad que no tienen representación del lenguaje, lo que la elección de ciertos tipos de narradores en los medios de la cultura contemporánea pone de relieve el simbolismo de la piel superpuesta que juega imágenes icónicas de las bandas, películas y dibujos animados o cómics. Estas imágenes son los residuos de las memorias individuales / colectivos lucía social y discursos sobre las relaciones de consumo de los sujetos sociales y nuevas sensibilidades derivadas de la coexistencia mediada tecnológicamente.

Palabras-clave: Cultura, Consumo, órgano de comunicación, la subjetividad.

\section{A LINGUAGEM DA EXPERIÊNCIA CORPORAL}

Uma perspectiva para compreender as relações de afeto entre jovens e alguns produtos simbólicos da indústria cultural por meio da narrativa de cinco entrevistados do interior de São Paulo e capital requer alinhavar as histórias do presente. As falas dos sujeitos conotam acontecimentos a partir da escolha de versões, da revelação de nuances emocionais e da oferta de explicações subjetivamente motivadas. Para compreendermos a dinâmica cotidiana presente nessas falas, recorremos a Agnes Heller (1985), que ressalta haver, em tal dinâmica, escolhas que se originam de heranças da tradição, do condicionamento social de 
tempo e lugar, juntamente com outras que obedecem a sutilezas nascidas de vínculos afetivos proporcionados pela vivência na cultura midiática de consumo. A moda, tributária dessa cultura, orienta várias escolhas dessa natureza, ao mesmo tempo abrigando opções subjetivas e ordenamentos sociais. A opção por fazer tatuagem é uma dessas escolhas. No tipo de tatuagem pesquisado aqui, há a eleição de imagens que estão permeadas pela relação de afetividade e cumplicidade com os produtos culturais massificados pela mídia ${ }^{3}$, o que vamos tentar explorar com o aporte teórico de vários autores.

Um dos suportes é Stuart Hall (2000) e suas discussões sobre identidades ou subjetividades contemporâneas. Buscamos entender como os motivos das tatuagens dos jovens adultos entrevistados ajudam em sua identificação e em sua diferenciação com os demais grupos existentes na teia social em que tais sujeitos se inserem. O corpus do estudo são as narrativas orais coletadas junto a cinco sujeitos entrevistados ${ }^{4}$. Adotamos o seguinte procedimento: num primeiro encontro, gravamos as narrativas em áudio e as transcrevemos; num segundo momento, gravamos em vídeo no estúdio, onde o silêncio e a presença de poucas pessoas propiciaram o surgimento de informações mais intimistas e com mais possibilidade de análise qualitativa de conteúdo, como sugere o método da história oral ${ }^{5}$. Com isso, pretendemos o resgate das memórias individuais e das experiências sensíveis de sujeitos do mundo do consumo que decidem tatuar símbolos da indústria cultural na pele. $\mathrm{O}$ resgate dessas memórias é também um esforço no sentido de um estudo de recepção específico, ou seja, da produção de sentido pelo receptor a partir da pertinência de influências midiáticas em seu cotidiano ${ }^{6}$. Neste caso, buscamos o levantamento de uma tipologia dos vínculos sensíveis que caracterizam as manifestações cotidianas desse receptor em relação aos produtos midiáticos e, para tanto, recorremos a Muniz Sodré (2006).

Para evitar um juízo de valor prejudicial à compreensão do processo de expressão dos indivíduos imersos na sociedade da informação midiática, optamos por trabalhar com o conceito de cultura de Edgar Morin ${ }^{7}$, que desenvolve a ideia de que a cultura é mais do que um conceito ou um princípio indicativo, mas a totalização dos processos que integram o modo como um problema é vivido. Dentro desse panorama, a noção de cultura oscila entre

\footnotetext{
${ }^{3}$ SODRÉ, Muniz. As Estratégias Sensíveis: Afeto, Mídia e Política. Petrópolis, RJ: Vozes, 2006 p. 12-15.

4 As entrevistas foram realizadas no estado de São Paulo entre abril e outubro de 2007 pelas pesquisadoras com três homens e duas mulheres. O. T. (homem, 34 anos), D. S. (mulher, 27 anos), D. F (homem, 24 anos), V. T. (homem, 23 anos) V. M (homem, 21 anos).

${ }^{5}$ Cf. QUEIROZ (1991).

${ }^{6}$ Cf. SOUZA (2006).

${ }^{7}$ Cf. o artigo Da culturanálise à política cultural. In: Revista Margem, PUC/SP, n ${ }^{\circ} 16$, p. 183-221, dez. 2002.
} 
diversos sentidos, indo da identificação com o saber das humanidades até um sentido mais total, ou seja, antropo-sócio-etnográfico. No sentido mais amplo, a cultura é constituída pelas representações, símbolos, mitos e ideias produtoras de crenças, valores, normas e memória histórica. No que interessa a este estudo, a cultura reflete a vivência, e incorpora elementos da visão psicológica mágica e arcaica que carrega os dados do real de uma intensa subjetividade e mobiliza estruturas emocionais durante a percepção. (Morin, 1997).

A representação linguística se insere nessa esfera, sendo também responsável por produzir o mundo humano. Assim, entendemos linguagem como um elemento denotador de estruturas profundas, as quais são elas próprias constituídas na linguagem. Segundo Humberto Maturana e Francisco Varela, as palavras denotam tanto objetos como estados de ânimo, o concreto e o abstrato, o existente e o inexistente, e as descrições tratam outras descrições como se fossem objetos. As interações acontecem no e por meio do domínio linguístico.

Isso acontece a nós, humanos: existimos em nosso funcionamento na linguagem, e conservamos nossa adaptação no domínio de significados que isso faz surgir. Fazemos descrições das descrições que fazemos... (como o faz esta frase)... Somos observadores e existimos num domínio semântico criado pelo nosso modo lingüístico. (Maturana; Varela, 2001, p. 233)

Nosso corpo existe dentro desse domínio e, mesmo sendo considerada a sua estrutura biológica, esse corpo também é denominação, representação, ou seja: linguagem. Portanto, o nosso corpo é também cultural e social, além de físico. A existência é, antes de tudo, corporal; a experiência do corpo é condição da existência social humana. Concomitantemente, "a percepção dos inúmeros estímulos que o corpo consegue recolher a cada instante é função do pertencimento social do ator e de seu modo particular de inserção cultural" (Le Breton, 2006, p. 56).

Assim, os símbolos que os sujeitos usam sobre os seus corpos e em suas peles são a expressão de vivências que se dão na esfera da linguagem e da cultura; do mesmo modo que testemunham essas vivências, os símbolos indicam uma experimentação singular do mundo, são afloramentos de subjetividade.

A construção das subjetividades depende dos corpos e do meio cultural e social em que se inserem estes corpos. Na sociedade contemporânea, a cultura está cada vez mais imbricada às fruições midiáticas, que ocorrem como experimentações de consumo, um consumo que é também apropriação de valores, identificação e diferenciação, que serve tanto para confirmar quanto para negar. E que, lastreando a expressão dos indivíduos, demonstra 
que também serve para negociar o que vem de fora com o que já existe dentro dos mundos social e individual. Por consequência, serve para pensar. ${ }^{8}$

\title{
2. PERPETUAÇÃO SIMBÓLICA E IDENTIFICAÇÃO SOCIAL
}

\author{
Apenas o céu sabe exatamente quando \\ o primeiro homem e mulher \\ adicionaram o primeiro ornamento em \\ seu corpo. Não muito tempo depois, \\ estou certo, foi feito pelo primitivo \\ colocando uma decoração permanente,
}

ou sinal de magia, sobre a pele.

George Burchett ${ }^{9}$

A assunção e declaração de pertença, as maneiras de identificação ou afirmação de subjetividade não se dão só pelas escolhas dos grupos sociais ou atividades profissionais a serem exercidas; os processos de subjetivação e identificação passam também pela visibilidade do corpo, pelos gestos e pela postura corporal (BOURDIEU, 1989). A linguagem dos corpos, que é reforçada por textos da cultura (roupas, adereços, tatuagens) denota pertenças, mas implica também a expressão distintiva das relações de poder que passam pelos signos da identificação e da desidentificação. Villaça e Goes (1998) citam Claude Rommeru ${ }^{10}$ para ilustrar que os homens são divididos em dois esquemas principais, de dimensão horizontal e vertical. A vertical é que implica a hierarquia dos valores, onde aparece a distinção entre corpo e espírito (platonismo, cristianismo e o islamismo); já o esquema horizontal ignora as hierarquias e coloca os seres e as coisas no mesmo plano. ${ }^{11} \mathrm{O}$ uso dos signos aponta para essas dimensões, imersos que se encontram num emaranhado de relações culturais e política, de modo que

pensar o corpo hoje é pensar suas performances, seus limites, numa visão que o contemple como um dos elementos constitutivos do amplo universo semiótico, no qual se produzem as subjetividades. (VILLAÇA; GOES, 1998, pp. 28-29).

\footnotetext{
${ }^{8}$ Cf. FEATHERSTONE (2005), CANCLÍNI (2005) e ROCHA; SILVA (2007).

${ }^{9}$ Famoso tatuador londrino (1872-1953).

${ }^{10}$ Autor francês não publicado no Brasil. Entre suas obras, citamos De la nature a l'histoire 1685-1794.

Paris : Pierre Bordas et fils, 1985.

${ }^{11}$ Sobre a verticalidade e a horizontalidade na cultura, cf. também PROSS (1980).
} 
Derrick de Kerckhove diz que o progresso tecnológico é o resultado de um esforço coletivo de criar melhores extensões de nosso corpo. Para o autor, a TV tem uma dimensão não apenas visual e auditiva, mas também tátil: ela "acaricia e impregna o seu significado por debaixo da nossa pele" (1997, p. 49). Em consonância com essa formulação, notamos que os entrevistados deste trabalho demonstraram que colocar os símbolos escolhidos dentro da cultura midiática em suas peles é a expressão incorporada, material, do bem simbólico de que se apropriam, ou ainda, incorporam. Seus corpos não desejam a alteridade digital, mas são corpos que deixam transparecer em suas superfícies as motivações culturais tanto quanto suas opções estéticas; mostram, como num outdoor, as escolhas daquilo que faz as existências de cada sujeito.

\section{TATUAGEM COMO EXISTÊNCIA}

“Existirmos: a que será que se destina?" A música "Cajuína" ${ }^{12}$, de Caetano Veloso, nos convida a refletir, assim como a tatuagem também nos convida a pensar sobre corpos que se expandem para além daquele que se tatua. Enquanto a escrita deste artigo caminhava, um anúncio comercial de cerveja na televisão mostrava a dúvida de um homem sobre o que tatuar em sua pele. Ele ouvia todas as opiniões e acabava desenhando algo monstruoso no próprio corpo. Outro comercial de automóvel apresentava várias jovens se reinventando em imagens sobrepondo-se umas às outras. Um grande número de imagens de jovens tatuados indicava que tatuar seria sinônimo de reinvenção de identidades.

Perante o bombardeio de imagens pela mídia sobre as inúmeras possibilidades identitárias, sobre os presentes sucessivos e a fragmentação do indivíduo nas sociedades ocidentais contemporâneas, surge como importante fazer algo permanente, fixo sobre o próprio corpo em mutação. O corpo funciona como um outdoor das escolhas subjetivas, uma vitrine da essência do ser. Por isso é que, segundo os entrevistados desta investigação, as tatuagens correspondem sempre a um período marcado por escolhas identitárias, indicando memórias e pertenças.

O conceito antropológico de identidade é marcado por dissensos conceituais. No entanto, para os objetivos deste artigo, optamos por pensar a identidade cultural - que implica sistemas de representações entre indivíduos e grupos a partir de um patrimônio simbólico compartilhado - conforme a perspectiva de Hall (2000). O autor discute o estatuto cultural contemporâneo das identidades, observando que as categorias de identidade e os

\footnotetext{
${ }^{12}$ Integrante do disco "Cinema Transcendental” (Polygram, 1979).
} 
processos de identificação se apresentam pulverizados e multifacetados pela diversidade de papéis sociais vividos pelos indivíduos. Além disso, os fenômenos do descentramento e deslocamento das identidades permitem perceber que essas identidades se manifestam de modo transitório, em contínuas transformações. O indivíduo, fragmentado e em constante fluxo no espaço (físico e simbólico) e no tempo (simbólico), ante a imensidão do universo e a finitude da sua vida singular, busca paradoxalmente a permanência simbólica com o recurso da alternância.

O depoimento de O. T. (34 anos, publicitário, sexo masculino), um dos entrevistados em nossa pesquisa, é uma sugestão disso. Quando O. T. muda algo em sua vida, sente que precisa marcar a sua pele, mudar a sua cor por meio de uma nova tatuagem. O verbo transformar está presente em toda a sua fala. Associando as tatuagens a sentimentos, ele busca sempre uma nova imagem para tatuar no corpo. Ao lidar com a tristeza, por exemplo, ele se sente renovado ao se tatuar; assim, chegou a vinte e sete imagens na pele reproduzindo logomarcas e outros símbolos da sociedade de consumo.

No filme "Senhores do crime" para mafiosos. No ritual que envolve os membros da máfia, o personagem Nikolai (Viggo Mortensen) é tatuado. Vários códigos e símbolos afirmam a identidade do sujeito perante a máfia russa sediada em Londres, o que remete à Yakuza, outro exemplo de crime organizado, desta feita japonês, também representado no cinema, cujos membros tatuam inteiramente o próprio corpo como forma de declarar sua adesão permanente ao grupo. Segundo Marcel Mauss (2003), para quem o corpo é necessariamente uma construção simbólica e cultural, toda sociedade utiliza formas gráficas e símbolos para marcar os corpos de seus membros.

O. T. informou que, desde criança, pensou em se tatuar. Sempre acreditou que a tatuagem, na qual consegue ver beleza, é algo muito expressivo em nossa sociedade. Ele ressaltou que o que lhe chama a atenção para o bom gosto de uma pessoa é o número de tatuagem que ela possui; por isso, procura conhecer garotas tatuadas. Para si, escolheu como primeira tatuagem (na perna) o símbolo do herói de quadrinhos Super-Homem. Ele mesmo o desenhou, já que trabalha também como designer gráfico. Acredita que o herói SuperHomem representa sua identidade porque sempre se considerou diferente das outras pessoas:

As pessoas, de um modo geral, acham a vida complicada. Eu me acho, desde quando escolhi a tatuagem, um vencedor como o Super- Homem, então, eu precisava daquela tatuagem pra me identificar perante as pessoas. Fiz esta tattoo com 28 anos, foi bem pensado. Então eu comecei a pesquisar e eu sempre achei legal aquele lance do Super-Homem, de ele ter uma

\footnotetext{
${ }^{13}$ Eastern Promises, Inglaterra - Canadá - EUA/ 2007.
} 
identidade secreta, de ele fazer as coisas para as outras pessoas, e é o que eu faço; faço para as pessoas que estão ao meu redor e nunca faço por mim, como o Super-Homem. (O.T.)

O. T. tem outras vinte e seis tatuagens, a grande maioria escolhida mais pelo seu gosto musical do que pelo apelo do personagem. Ele não esquece que o soldado híbrido do Linkin Park ${ }^{14}$ foi a tattoo que mais doeu, a que mais verteu sangue. A tatuagem de elefantes que rodeia seus braços foi feita em homenagem a Michael Peter Balzary ${ }^{15}$, segundo ele o melhor baixista do planeta. Outra tatuagem em homenagem à banda é de uma moça tocando um baixo acústico, além de mais duas reproduzindo tatuagens que Anthony Kiedis ${ }^{16}$ tem nos braços, uma representando o amor e outra representando a paz.

As tatuagens estão ligadas também aos acontecimentos da vida de O. T., que se tatua quando acontece algo bom ou ruim. Ele acentua que a vontade de tatuar vem de dentro, lhe dá prazer:

Eu costumo realizá-las rapidamente em situações [em] que não consigo manter o controle; então, eu achava que, para poder mudar e esquecer aquele pouco que eu deixei para trás, precisava fazer uma tatuagem nova. (...) É assim que carrego todas elas. Todas marcam um momento. Duas foram uma homenagem a uma pessoa [de] que eu gostava, mas nada de colocar nomes. As pessoas mudam com o tempo, não adianta colocar nomes; [por isso], sempre são símbolos da indústria cultural. Sou publicitário e amo as marcas e produtos da indústria. Vou continuar tatuando até morrer. (O.T.)

Para O. T., a mais importante das suas tatuagens continua sendo a primeira, do SuperHomem:

Eu mudo através [sic] da tatuagem, já que não posso mudar de rosto. Quando você fica com determinada pessoa, dá impressão que você fica usado. Para renovar, você tem que fazer alguma coisa. Algumas pessoas mudam o cabelo, outras preferem roupa, outras viajam, e eu faço uma tatuagem nova, então cada dois ou três meses, eu faço alguma nova, daí dá a impressão de que eu estou renovado. (O.T.)

Gilles Lipotvesky, em uma palestra proferida no Brasil ${ }^{17}$, comentou sobre o mundo atual, que nos convida a mudar a cada instante para estarmos em evidência. Para ele, vivemos em um mundo que intensifica o conceito de modernidade principalmente no que se refere à busca da autonomia, prazer e renovação, consumo e individualização. O presente é

\footnotetext{
${ }^{14}$ Linkin Park é uma banda de rock new metal dos Estados Unidos formada em 1996.

${ }^{15}$ Baixista Flea, da Red Hot Chili Peppers, banda norte-americana de rock eclético formada em 1983.

${ }^{16}$ Vocalista da banda Red Hot Chili Peppers.

${ }^{17}$ Palestra intitulada A inquietude do futuro: o tempo hiper-moderno no Café Filosófico no Espaço Cultural CPFL em Campinas/SP, em 26/08/2004. Disponível em DVD (CulturaMarcas, 2006) com curadoria de Jorge Forbes.
} 
fundamental, mas não deixamos de nos preocupar com o futuro. Buscamos o presente de forma hedonista com ênfase na informação e na comunicação; a tônica é o imediatismo.

É por estar dessa forma num mundo em contínua mudança que a motivação dos tatuadores do presente emerge. D. S. (27 anos, estudante de história, sexo feminino), pensou em se tatuar quando tinha uma banda de punk rock na adolescência e morava em uma cidade bem pequena do interior do estado de São Paulo. Ela tatuou nas costas a imagem colorida e bem grande de Kenny, personagem do South Park ${ }^{18}$, e disse ter feito o desenho por achá-lo esteticamente delicado, "fofo":

Fiz o desenho do Kenny [quando] eu tinha acabado de completar dezoito. Escolhi porque eu simpatizo com o personagem. Na série do desenho, ele é um personagem bom e legal em relação aos seus outros amigos, e sempre morre nos fins dos episódios. Então, para dar uma alegria ao Kenny, decidi colocá-lo em mim; assim ele só morreria se eu também morrer. Louco, não? (D.S.)

Ela sentia muito carinho pelo desenho; hoje, esse carinho diminuiu, mas ela ainda gosta, embora agora haja outros símbolos que gostaria de desenhar em si mesma. Afirmou que não foi motivada por ninguém para fazer a tattoo, e que gosta da conotação tribalista que envolve o ato de desenhar sobre o próprio o corpo.

D. F. (24 anos, cabeleireiro e tatuador, sexo masculino) tem desenhada em todo o corpo a banda britânica de pop rock Spice girls ${ }^{19}$. As tatuagens são das cinco garotas da banda (Emma Bunton, Geriram Haliwell, Melanie B., Melanie C. e Victoria Beckham), que estão desenhadas ao redor das suas pernas. Tem também a letra da música da banda intitulada Spice up your life $e^{20}$ nas costas. A música foi utilizada como parte da divulgação do desodorante Impulse Spice e a fragrância vinha também na capa do álbum. Para D. F. , que não se refere a este episódio, a motivação é outra:

Tatuei as Spice girls porque surgiu a banda... Conheci elas através [sic] de uma professora de inglês que foi pra Europa e trouxe um CD pra mim e disse 'acho que você vai gostar desse CD'. Aí, eu comecei a ouvir as musicas e fui gostando, achei interessante um clipe delas, todo feito em animação, gostei muito do desenho... Aí, já que eu gosto da banda, eu vou tatuar porque eu acho legal. (D.F.)

A letra da musica Spice Up Your Life, segundo a narrativa de D. F., expressa independência, responsabilidade e conseguir viver sua vida por você mesmo: "Sempre gostei

\footnotetext{
${ }^{18}$ Desenho animado para adultos criado por Matt Stone e Trey Parker e exibido a partir de 1997 pelo canal de televisão norte-americano Comedy Central. Exibido no Brasil a partir de 1998 em TVs por assinatura e na MTV.

${ }^{19}$ Formada em 1993 e desfeita em 2008.

${ }^{20}$ A música faz parte do álbum Spiceworld, lançada também como disco compacto simples (single) promocional em 1997.
} 
de ter vontade, de ter a liberdade... A gente sempre vai buscando a liberdade e acho que a tatuagem ajudou eu me $[\mathrm{sic}]$ expressar livremente e também a correr atrás dessa vontade de ser livre" (D.F.).

Todas as sociedades criam regras para distinguir seus membros. O corpo expressa isso, do mesmo modo como expressa as emoções e disposições do indivíduo. Os sinais dessa expressão (semblante, gestos, posturas) são sutis, mas perceptíveis, ainda que de forma inconsciente, pelos membros de uma dada cultura. Conforme David Le Breton,

\begin{abstract}
os sinais do rosto e do corpo inserem o indivíduo no mundo, mas tratando-se invariavelmente do compartilhamento de uma comunidade social, eles o transcendem. Um imenso domínio de expressão está apto a colher uma gama de emoções e a traduzi-las aos olhos dos demais, tornando-as compreensíveis e comunicáveis. Os movimentos do rosto e do corpo formam um terreno de metamorfoses espetaculares e permanentes que, no entanto, empregam modificações ínfimas de disposição. Eles se tornam facilmente uma cena na medida em que oferecem à leitura os sinais que revelam a emoção e o papel desempenhado na interação. (2009, p 42)
\end{abstract}

A distinção em relação ao restante dos grupos sociais, assim como a posse de um patrimônio simbólico compartilhado, dá o sentido de pertença aos membros de comunidades, mesmo que sejam efêmeras como as que compõem as sociedades contemporâneas do consumo simbólico massivo. Dizer aquilo que não se é constitui uma forte afirmativa sobre o que se é. Há um olhar seletivo do indivíduo para o que é considerado significativo, estético, agradável, repugnante, interessante e importante tanto nos acontecimentos da vida de cada um como nos símbolos que ostentam as narrativas desses acontecimentos. Essa seletividade reflete vivências que são singulares, mas significadas socialmente. A música "Protesto pessoal" ${ }^{21}$, da banda paulistana Dona Zica exemplifica isso ao afirmar que a sociedade começa na testa de cada indivíduo. Nessa perspectiva, as escolhas pessoais refletem o grupo, que está introjetado no indivíduo. Mas por que expor isso na própria pele?

O entrevistado D. F. disse que começou a pensar em se tatuar quando conheceu a tatuagem artística. Fez um curso de tatuador e começou a escolher o que tatuar. "Acredito que acontecem coisas na vida da gente que a gente quer marcar. São histórias que marcam e você vai desejando não esquecer nunca desses momentos; então, você decide gravar no corpo.” (D. F.)

D.F. tem em si vários símbolos da indústria cultural, e pretende continuar tatuando os espaços vazios:

\footnotetext{
${ }^{21}$ Da autoria de Iará Rennó, constante do álbum "Composição" (2003), que tem o refrão: "no fundo de cada um / pulsa um novo mundo / cada indivíduo é um universo vivo / e você mesmo seu maior inimigo / no fundo / de cada um pulsa um novo mundo / cada indivíduo é mais uma peça que completa / essa equação complexa".
} 
O Snoopy eu fiz porque pra mim ele representa liberdade; ele não depende na história, não depende do dono dele, é independente, e acho que é isso. Só que, ao mesmo tempo [em] que ele é independente, ele necessita do carinho do dono, então eu acho que é isso mesmo. (D. F.)

D. T. se tatua desde os 16 anos e o Snoopy foi sua primeira tatuagem. Começou a fazer as Spice girls quando tinha 22 anos e terminou aos 23, cobrindo as pernas e as costas inteiras. Fez, também nos braços, "A criação de Adão" 22 , que mostra o encontro dos dedos de Deus e do homem para simbolizar no seu corpo o contato com o divino. Já V.T. (23 anos, estudante de publicidade) escolheu a banda Strung $\mathrm{Out}^{23}$ para tatuar em sua perna e em seu pé. Disse que adorava desde a adolescência ir a bares de rock. Seus modelos eram sempre os rapazes mais velhos que tinham tatuagem e tocavam em bandas. Ao mesmo tempo, ela gostava de desenhar e tinha muito interesse em artes. Desejava fazer taguagens desde muito cedo, mas os pais sempre foram contra e não contribuíam financeiramente para a construção da tatuagem:

... eu pensei bastante antes de fazer porque é uma decisão fixa, única e tal, e só pensei na banda Strung Out. Sempre gostei muito das letras, das melodias, e também eu gostava do símbolo dela, daí eu resolvi tatuar o símbolo da banda. Tinha o vocal da minha banda que me incentivou, ele era tatuador e me deu um desconto. (V.T.)

A música é um elemento de pertença para os jovens nas sociedades ocidentais. Os estilos das bandas são reverenciados e seguidos por jovens que, assim, definem seus grupos de amigos e se distinguem dos demais jovens na sociedade massificada ${ }^{24}$. V. T. ainda tatuou a banda Green $D_{a y}^{25}$ na pele por identificação com o ritmo; no caso da Strung Out, a identificação foi mais com as letras, que tratam sempre dos fatos que acontecem atualmente, de política e da sociedade, além de sentimentos pessoais, embora o ritmo hardcore também seja importante.

V. M. (21 anos, estudante de publicidade) tatuou a banda $K i s s^{26}$ em seu corpo e se veste como os integrantes da banda. Como os demais jovens, não só a tatuagem expressa as suas identificações, mas também suas roupas e sua postura corporal. Disse que resolveu mudar a forma de se vestir quando a banda veio para Brasil em abril de 1999 em um show no

\footnotetext{
${ }^{22}$ Afresco pintado por Michelangelo Buonarroti na Capela Sistina, no Vaticano, aproximadamente em 1511 .

${ }^{23}$ Banda norte-americana de punk rock formada em 1992 na Califórnia.

${ }^{24}$ Para maior aprofundamente no tema, cf. BORELLI, S. H. S.; ROCHA, R. M.; OLIVEIRA, R. A. et alii. Jovens na cena metropolitana: percepções, narrativas e modos de comunicação. São Paulo: Paulinas, 2009.

${ }^{25}$ Banda californiana (EUA) de punk rock formada em 1987.

${ }^{26}$ Banda norte-americana de hard rock formada em 1973 conhecida pelo uso de maquiagem e concertos extravagantes.
} 
autódromo de Interlagos, em São Paulo. O irmão de V. M. foi e trouxe um CD e uma camiseta de presente para ele. A paixão começou neste instante e perdura até em sua maneira de se colocar perante a câmera; o entrevistado utiliza os gestos da banda Kiss:

É uma coisa que vai continuar comigo pelo resto da vida. O ano de 1999 foi um marco para mim. Escolhi de maneira tranquila o símbolo da banda para tatuar na minha pele e, no ano que vem, vou fechar minhas $\operatorname{costas}^{27}$ com o símbolo do Kiss. Esta primeira tatuagem foi um desenho que eu achei bonito, que é a formação original deles. Queria ter primeiro essa tatuagem para depois fazer as outras deles. Minha paixão é difícil explicar, quase ninguém entende; só quem gosta realmente de uma coisa sabe do que eu tô [sic] falando. Não é uma coisa que dá p'ra eu sair explicando p'ra todo mundo.

O sentimento de pertença no mundo contemporâneo, em razão da atomização dos indivíduos com a complexificação das sociedades, o modo de vida capitalista, a concentração populacional urbana, o encolhimento das famílias e a mudança nas condições de agregação comunitária, tem outras necessidades. Estamos em plena construção de novos mecanismos de identificação e distinção, como discute Canclíni:

\begin{abstract}
Junto com a degradação da política e a descrença em suas instituições, outros modos de participação se fortalecem. Homens e mulheres percebem que muitas das perguntas próprias dos cidadãos - a que lugar pertenço e que direitos isso me dá, como posso me informar, quem representa meus interesses - recebem sua resposta mais através do consumo privado de bens e dos meios de comunicação de massa do que nas regras abstratas da democracia ou pela participação coletiva em espaços públicos.” (1999, p. 37)
\end{abstract}

\title{
4. UM ESTANDARTE DE SI PRÓPRIO
}

Walter Benjamin afirmava, em seu texto "O narrador" (1994), que há uma crise da recepção produtiva porque abandonamos a forma de narrar as experiências que faz o ouvinte se tornar um novo relator. Isso pode implicar a incapacidade de verbalizar nossas escolhas, nossos anseios, nossas vivências, mas nossa expressão disso talvez se traduza, entre outras possibilidades, pela escolha de imagens do corpo e de imagens sobrepostas ao corpo. Há um enorme volume de informações circulando pelas mídias, e o excesso de informações resulta, segundo Morin, em miséria informacional ${ }^{28}$. Como lidar com informações que, fragmentadas e generalizadas, perdem o sentido? Como construir significados num mundo em que tudo significa, assolados que estamos por uma profusão de símbolos efêmeros, por possibilidades

\footnotetext{
${ }^{27}$ Tatuar as costas por completo.

${ }^{28}$ Cf. MORIN (1986).
} 
quase infinitas de alternância identitária e pelo apagamento dos limites entre o eu e o outro? A televisão, o cinema e a internet trazem para dentro de nossas casas o distante, o estranho, o passado e o futuro. Como nos afirmarmos como seres singulares e nos perpetuarmos simbolicamente num mundo em constante mudança?

O. T. (34 anos) disse que coloca suas mudanças na pele, se renova a cada nova tatuagem, e um super-herói de quadrinhos simboliza tudo isso. D. S. (27 anos) tatuou um personagem de desenho animado a fim de lhe dar mais tempo de vida; para ela, é importante o caráter tribal da tatuagem e o seu papel na representação dos anseios. Já para D. F (24 anos), a tatuagem é um argumento para a liberdade com que tanto sonhava; ele buscou a formação de tatuador para melhorar os traços que tatua em sua pele. V. T. (23 anos) decidiu tatuar o que o identifica; as letras das músicas da banda que carrega na pele falam muito de seu olhar para o mundo que o rodeia. V. M (21 anos) escolheu sua paixão, uma banda de música, ainda cedo, aos 16 anos; agora se veste como os integrantes da banda, tem a postura e o olhar deles e disse que vai tatuar a banda nas costas por inteiro.

Traduzir as escolhas de cada um na forma de ícones a serem exibidos socialmente é um elemento de distinção dos que se tatuam em relação a determinados grupos sociais e faixas etárias. $\mathrm{O}$ fato de que diversas sociedades pratiquem isso ao longo dos tempos e que vários canais por assinatura transmitam sessões de tatuagem ${ }^{29}$ não elimina a indagação que os tatuados geram ao conviver com os não tatuados. Até a ficção científica já se ocupou do tema com o livro de contos de Ray Bradbury, $O$ homem ilustrado ${ }^{30}$, que trabalha com a fascinação que sentimos ao olhar uma pele marcada, artificialmente colorida, simbolizando claramente algo para além de si mesma. Buscar entender esses símbolos com o auxílio das falas daqueles que estandartizaram suas preferências e estilos de consumo cultural na pele é um recurso para acompanhar com lucidez as mudanças que ocorrem no cotidiano da nossa sociedade. Essas mudanças não são superficiais; elas produzem, juntando tecnologias de ponta e costumes arcaicos, sensibilidades novas para quem nela vive e que precisa, com os artifícios de que dispõe, afirmar sua vida, sua individualidade e sua pertença sem deixar de ser si mesmo.

\footnotetext{
${ }^{29}$ Cf., p. ex., People\&Arts, canal digital norte-americano transmitido no Brasil.

${ }^{30}$ Portugal: Livros do Brasil, 1959.
} 


\section{REFERÊNCIAS BIBLIOGRÁFICAS}

BENJAMIN, W. O narrador: considerações sobre a obra de Nikolai Leskov. Magia e Técnica, arte e política, ensaios sobre literatura e história da cultura. São Paulo: Brasiliense, 1994.

BOURDIEU, P. O poder Simbólico. Lisboa: RJ, Difel, 1989.

CANCLINI, N. G. Consumidores e Cidadãos. 5a Ed. Rio de Janeiro: Editora UFRJ, 1999.

FEATHERSTONE, M. (org). Body Modification. London: Sage Publication Ltd, 2005.

HALL, S. A identidade cultural na pós-modernidade. Rio de Janeiro: DP \& A. 2000.

HELlER, A. O cotidiano e a história. Rio de Janeiro: Paz e Terra.1985.

KERCKHOVE, D. A Pele da Cultura. Lisboa: Relógio D’Água Editores, 1997.

LE BRETON, D. A Sociologia Do Corpo. Petrópolis: Editora Vozes, 2006. As Paixões Ordinárias: Antropologia das emoções. Petrópolis:, Vozes, 2009

QUEIROZ, M. I. P. Variações sobre a técnica de gravação no registro da informação viva. São Paulo: T.A. Queiroz, 1991.

MATURANA, H. e VARELA, F. A árvore do conhecimento - as bases biológicas da compreensão humana. São Paulo: Pala Athenas, 2001.

MAUSS, M. Sociologia e Antropologia. São Paulo: Cosac \& Naif, 2003.

MORIN, E. O cinema ou o homem imaginário. Lisboa: Relógio D’água/Grande Plano, 1997. Cultura de massas no século XX: o espírito do tempo - Neurose. Vol. I. Rio de Janeiro: Forense Universitária, 1986.

PROSS, H. Estructura simbólica del poder. Barcelona: Editorial Gustavo Gili, 1980.

ROCHA, R. M. e SILVA, J. C. Consumo, cenários comunicacionais e subjetividades juvenis. In: E-Compós $\mathrm{n}^{\circ}$ 09, agosto de 2007. Revista da Associação Nacional dos Programas de Pós-Graduação em Comunicação. Disponível em: http://www.compos.org.br/files/18ecompos09_Rose_Josimey.pdf

SODRÉ, M. As estratégias Sensíveis: afeto, mídia e política. Petrópolis: Vozes, 2006.

SOUZA, M. W. Recepção midiática: linguagem de pertencimento. Revista Latinoamericana de Ciencias de la comunicación. São Paulo: ALAIC. jan-jun.ao 2. no, 2. 2005.p10-21.

TRINDADE, E. e PAVAN, M. A. Memória da pele e histórias do consumo: marcas e produtos tatuados no corpo. Texto apresentado no GT História da Publicidade e Propaganda do VI Congresso Nacional de História da Mídia da Rede Alcar na UFF/Rio de Janeiro, maio de 2008. 
Tatuagem: cultura de massas e afirmação subjetiva incorporadas

de Maria Ângela Pavan e Josimey C. Silva

VILLAÇA, N. e GOES, F. Em nome do corpo. Rio de Janeiro: Artmidia/Rocco, 1998.

Artigo recebido em 1/3/2010.

Aprovado em 6/4/2010. 